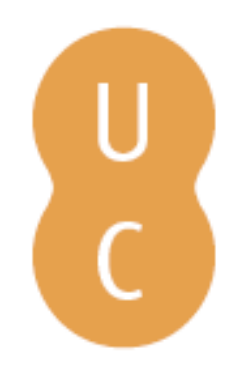

\title{
pommalina
}

\section{Accountability regimes and financial reporting in government: a comparison of China} and Australia

Autor(es): $\quad$ Neilson, John; Qi, Zhang

Publicado por: Imprensa da Universidade de Coimbra

URL

persistente: URI:http://hdl.handle.net/10316.2/32169

DOI: $\quad$ DOI:http://dx.doi.org/10.14195/978-989-26-0422-0_2

Accessed : $\quad$ 26-Apr-2023 15:15:46

A navegação consulta e descarregamento dos títulos inseridos nas Bibliotecas Digitais UC Digitalis, UC Pombalina e UC Impactum, pressupõem a aceitação plena e sem reservas dos Termos e Condições de Uso destas Bibliotecas Digitais, disponíveis em https://digitalis.uc.pt/pt-pt/termos.

Conforme exposto nos referidos Termos e Condições de Uso, o descarregamento de títulos de acesso restrito requer uma licença válida de autorização devendo o utilizador aceder ao(s) documento(s) a partir de um endereço de IP da instituição detentora da supramencionada licença.

Ao utilizador é apenas permitido o descarregamento para uso pessoal, pelo que o emprego do(s) título(s) descarregado(s) para outro fim, designadamente comercial, carece de autorização do respetivo autor ou editor da obra.

Na medida em que todas as obras da UC Digitalis se encontram protegidas pelo Código do Direito de Autor e Direitos Conexos e demais legislação aplicável, toda a cópia, parcial ou total, deste documento, nos casos em que é legalmente admitida, deverá conter ou fazer-se acompanhar por este aviso.

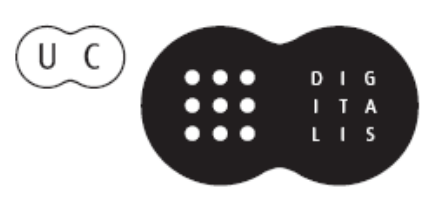




\section{Implementing Reforms in Public Sector Accounting}

Susana Jarge

Editor

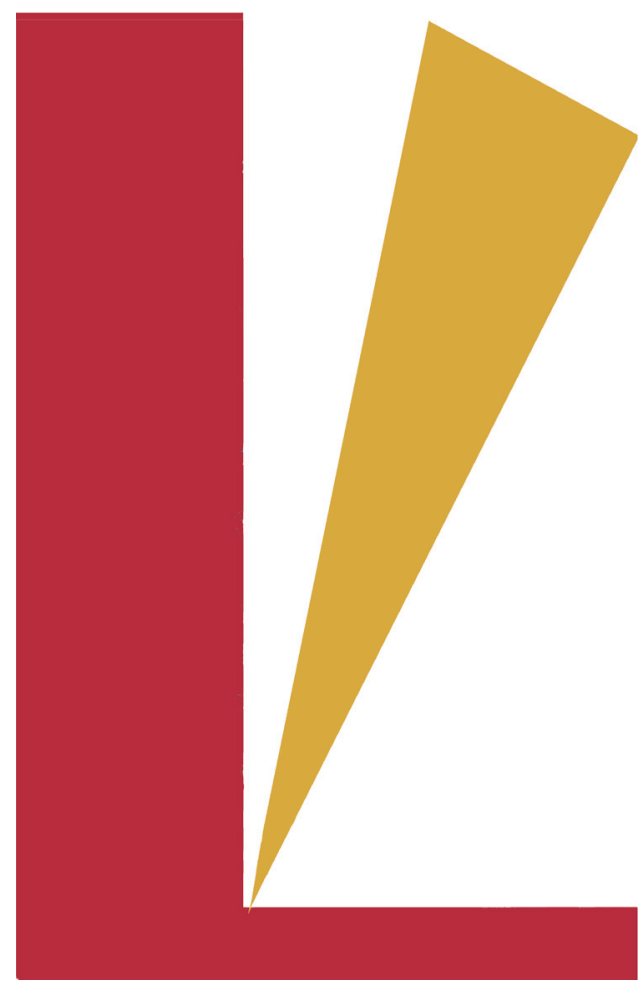


(Página deixada propositadamente em branco) 


\section{Implementing comparative Interational Reforms Governmental in Public Sector Accounting Accounting}

Susana Jorge Editor 
COORDENAÇÃO EDITORIAL

Imprensa da Universidade de Coimbra

Email: imprensauc@ci.uc.pt

URL: http://www.uc.pt/imprensa_uc

CONCEPÇÃO GRÁFICA

António Barros

\section{PAGINAÇÃO}

Simões \& Linhares, Lda.

\section{EXECUÇÃO GRÁFICA}

Simôes \& Linhares, Lda.

ISBN

978-989-8074-39-3

DEPÓSITO LEGAL

$281657 / 08$

\section{OBRA PUBLICADA COM O APOIO DE:}
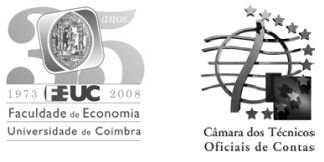

(C) Agosto 2008, IMPRENSA DA UNIVERSIDADE DE COIMBRA 
John Neilson

Zhang Qi

\section{ACCOUNTABILITY REGIMES AND FINANCIAL REPORTING IN GOVERNMENT: A COMPARISON OF CHINA AND AUSTRALIA}

\section{Introduction}

The governmental and public sector structures of countries around the world have evolved differently with many varying forms and structure of government now evident. These governmental structures can range from a centralist, authoritarian system with major government directions to a laissez-faire system with a small government structure and only minimal intervention by the government. A number of former British colonies have evolved a system of government with at least some basis of a 'Westminster' style of government. Some countries have evolved their governments and its responsibilities based on a presidential style of government where much of the authority and decision making is centred on a central president. Others have evolved a system whereby Parliament and its members are the source of power and authority.

Some systems of government within a country as a whole are controlled/directed from a central point and pervade all areas of the public sector throughout the country whilst other have developed a more devolved, 'federalist' structure where each tier of government is empowered with similar authorities and responsibilities.

Regardless of the manner in which governments have evolved, major processes of change have occurred in the public sector whereby public sector structures, responsibilities and reporting requirements etc have been subject to major reforms. Much of this reform commenced in Western countries in the mid 1980s but has now spread widely to embrace many countries with varying forms of government. These reforms have been given varying titles included New Public Management, Public Sector Financial Management Reforms etc but they have all been directed at improving the efficiency, effectiveness and accountability of governments and the public sector generally.

This paper undertakes a review of the evolution and current structure of the governments and public sectors of two quite diverse countries, those of China and Australia. China has evolved a centralist system of government resulting from a major revolution whereby the central government exerts major control over all levels of government. However Australia, a former British colony, has adopted a more 'federalist' 
system of government based on a distinct allocation of responsibilities and powers between the three tiers of government - federal, state and local.

In addition the paper reviews the important public sector reforms which have occurred in both countries over the past two decades and discusses the impact of these reforms on the accountability, roles and financial reporting of the public sector. The period from the late 1980 s to the start of the $21^{\text {st }}$ century have been a period of major reforms to many aspects of the public sector throughout a considerable number of countries. These reforms include changes in the actual structure of the public sector as well as in its systems of governance, accountability and the budgeting and reporting of results.

Section 1 of this paper contains an overview of the government and public sector structure and important roles within China. The section which follows details the Australian governmental structure and its division into three tiers of Federal, State and Local government. Section 3 undertakes a review of the major reforms which have been implemented in the Public Sector of both countries whilst Section 4 reviews the changes made to the budgeting and financial reporting processes. The final section contains the summary of the paper with a comparison of the reforms and practices in each country.

\section{Government and the Public Sector of China}

The structure of the public sector in China is based on a 'centralist' model whereby decision making, authority and reporting stem from a 'top down' basis. In this centralist model, there are complex relationships existing within the government system and between the governments and People's Congresses.

\subsection{Central Level of Government}

At the central level, the major relationships exist between the National People's Congress and the State Council and between the State Council and its ministries or commissions.

\subsubsection{National People's Congress (NPC)}

The National People's Congress of the People's Republic of China is the highest body of state power. Its permanent body is termed the Standing Committee of the National People's Congress. The National People's Congress and its Standing Committee exercise the legislative power of the state. The National People's Congress, elected for a term of five years, is composed of deputies elected from the provinces, autonomous regions, municipalities directly under the Central Government and special administrative regions and of deputies elected from the armed forces.

The National People's Congress has the power to remove from office a number of senior positions including the president and the vice president of the People's 
Republic of China; the premier, vice premiers, state councillors, ministers in charge of ministries or commissions, the auditor-general and the secretary-general of the State Council and the chairman of the Central Military Commission. In addition, the National People's Congress elects, and has the power to recall, members of its Standing Committee.

\subsubsection{Central Government}

The State Council, that is, the Central People's Government, of the People's Republic of China is composed of the premier, the vice premiers, the state councillors, the ministers in charge of ministries, the ministers in charge of commissions, the auditor-general and the secretary-general. The State Council is the highest body of state administration and is responsible to and reports on its work to the National People's Congress. The term of office of the State Council is the same as that of the National People's Congress.

The ministries and commissions are the integrants of the State Council, which can issue orders, directives and regulations within the jurisdiction of their respective departments and in accordance with the law and the administrative rules and regulations, decisions and orders issued by the State Council. Ministers in charge of ministries or commissions of the State Council are responsible for the work of their respective departments and they convene and preside over ministerial meetings or general and executive meetings of the commissions to discuss and decide on major issues in the work of their respective departments.

The State Council establishes an auditing body, the National Auditing Office (NAO), to supervise through auditing, the revenue and expenditure of all departments under the State Council and of the local governments at various levels, and the revenue and expenditure of all financial and monetary organizations, enterprises and institutions of the state. Under the direction of the premier of the State Council, the NAO assists the Auditor-General to independently exercise its power of supervision through auditing in accordance with the law, subject to no interference by any other administrative organ or any public organization or individual.

\subsection{Local Level of Government}

People's Congresses and People's Governments are established in provinces, municipalities directly under the Central Government, counties, cities, municipal districts, townships, ethnic townships and towns ${ }^{1}$. In China, there are 34 local governments at the province level.

\footnotetext{
${ }^{1}$ In addition, six Special Economic Zones have been established in China including Shenzhen city, Shantou city, Zhuhai city, Xiamen city, Hainan province (the whole province), Pudong district of Shanghai city.
} 


\subsubsection{Local People's Congresses}

Local people's congresses at various levels are local bodies of state power, which ensure the observance and implementation of the Constitution and the law and the administrative rules and regulations in their respective administrative areas. Within the limits of their authority as prescribed by law, the local Peoples Congresses adopt and issue resolutions and examine and decide on plans for local economic and cultural development and for the development of public services. Local People's Congresses at and above the county level examine and approve the plans for economic and social development and the budgets of their respective administrative areas and examine and approve reports on their implementation. They have the power to alter or annul decisions of their own standing committees.

Deputies to the People's Congresses of provinces, municipalities directly under the Central Government and cities divided into districts are elected by the People's Congresses at the next lower level, and they are subject to supervision by the units which elected them. Deputies to the People's Congresses of counties, cities not divided into districts, municipal districts, townships, ethnic townships and towns are elected directly by their constituencies, and they are subject to supervision by them. The term of office of local People's Congresses at the various levels is five years. The electoral units and constituencies, which elect deputies to local People's Congresses at various levels, have the power to recall the deputies according to procedures prescribed by law.

The people's congresses of provinces and municipalities directly under the Central Government and their standing committees may adopt local regulations, which must not contravene the Constitution and the law and the administrative rules and regulations, and they shall report such local regulations to the Standing Committee of the National People's Congress for the record.

Local People's Congresses at their respective levels elect, and have the power to recall, governors and deputy governors, or mayors and deputy mayors, or heads and deputy heads of counties, districts, townships and towns. Local People's Congresses at and above the county level elect, and have the power to recall, presidents of People's Courts and chief procurators of people's procuratorates at the corresponding level.

\subsubsection{Local People's Governments}

Local People's governments at various levels are the executive bodies of local bodies of state power as well as the local bodies of state administration at the corresponding levels, which are responsible and report on their work to the state administrative bodies at the next higher level and the people's congresses at the corresponding levels. Local People's Governments at various levels throughout the country are state administrative bodies under the unified leadership of the State Council and are subordinate to it.

Governors, mayors and heads of counties, districts, townships and towns assume overall responsibility for local People's Governments at various different levels. The term of office of local People's Governments at various levels is the same as that of the People's Congresses at the corresponding levels. 
Local People's Governments at and above the county level, within the limits of their authority, as prescribed by law to conduct administrative work concerning the economy, education, science, culture, public health, physical culture, urban and rural development, finance, civil affairs, public security, ethnic affairs, judicial administration, supervision and family planning in their respective administrative areas; issue decisions and orders; appoint or remove administrative functionaries, train them, appraise their performance and reward or punish them (Constitution of People's Republic of China, 2004). People's Governments of townships, ethnic townships, and towns execute the resolutions of the people's congress at the corresponding level as well as the decisions and orders of the state administrative organs at the next higher level and conduct administrative work in their respective administrative areas.

Local People's Governments at and above the county level direct the work of their subordinate departments and of People's Governments at lower levels, and have the power to alter or annul decisions of their subordinate departments and of the People's Governments at lower levels.

Auditing bodies are established by local People's Governments at and above the county level. Local auditing bodies at various levels independently exercise their power of supervision through auditing in accordance with the law and are responsible to the people's government at the corresponding level and to the auditing body at the next higher level.

\subsection{Power and Responsibility Relationships Within the Chinese Government}

The structure of the Chinese governments is very special and involved and is based on a 'centralist' model whereby decision making, authority and reporting stems from a 'top down' basis. There is close relationship between central government and local governments. One local government usually reports on its work to both the People's Congress in the corresponding level and the government in next higher level. All local governments at the various levels fall under the unified leadership of the State Council and are subordinate to it. Therefore within the public sector of China, there are complex relationships among and between the various levels of government and People's Congresses.

The existence of these relationships within the China governments between firstly, the whole public and the elected people's congress, secondly, the people's congress and the government in respective level and thirdly, the government and the government in next lower level can be illustrated by reference to the Constitution of People's Republic of China.

An additional factor which influences the relationships within the China governments is that there is only one ruling party in China, the Chinese Communist Party (CCP). The CCP can nominate the main officials of government to People's Congresses and directly appoint the important officials of party, including the General Secretary, in the government who are the actual leaders of the government ${ }^{2}$. In China, there are some

\footnotetext{
${ }^{2}$ For example, in most cities the mayors are always the vice-secretaries of corresponding local organizations of CCP.
} 
minor non-communist parties who may be able to influence the government by delegating their members to the Chinese People's Political Consultative Conference (CPPCC).

\section{Government and the Public Sector in Australia}

The Australian system of government and structure of the public sector is based on a 'federalist' model whereby there are normally distinct divides between the roles of the three tiers of government, these being federal, state and local government. The powers of the federal and state governments only are set out in the Constitution of Australia

\subsection{Federal Government and Public Sector}

The Commonwealth of Australia which was established on 1 January 1901 consists of three aspects of government, these being the legislative, executive and judiciary, each of which is separate and distinct from the other. The Australian Constitution details the powers of each of the separate areas of government.

\subsubsection{The Federal Executive Level}

The Federal Executive tier of government is responsible for the day to day operations of the government and its various departments and agencies. Australia operates under a 'cabinet' style of government and the cabinet of ministers (which comprises senior ministers of the government) is the major decision making body of the government. (www.aph.gov.au/parl.htm, 12 Jan 07)

Each minister is responsible for one or more agencies of the federal government and has responsibility to the Parliament for the efficient running of these agencies. Government agencies are basically divided into departments (normally the major arms of government) such as education, defence, social security and foreign affairs or statutory authorities which are usually established by the Parliament and have a Board to oversee the operations of the agency. The statutory authority is still responsible for its activities to a Minister of the Parliament.

The Parliament, on the recommendation of the Prime Minister, appoints an Auditor-General to be the head of the Australian National Audit Office (ANAO) which is responsible for undertaking audits of all Federal government agencies. The Auditor-General prepares an annual report of the operations of the ANAO and its audits and submits this to the Federal Parliament. The ANAO has no responsibility or authority to undertake audits of state or local governments.

\subsubsection{Federal Judicature}

The Australian Constitution provides for the establishment of the highest court in Australia, the High Court of Australia and also for other courts that the Federal Parliament 
may wish to create. The High Court judges are all appointed by the Governor-General of Australia after advice from the Federal Executive Council. The basic function of the High Court is to interpret and apply the laws of Australia. The High Court of Australia is the highest appellant court in Australia and also has responsibility to rule in the case of disputes in relation to any federal election and the declaration of the result. Other courts of the Federal Government include the Federal Court and the Family Court of Australia.

\subsection{The State Governments and Public Sector}

The six state governments and public sector closely mirror that of the Federal government and Parliament in that they have three levels of the public sector, the legislative, executive and the judiciary.

\subsubsection{State Public Sector Systems}

With the exception of Queensland (which only has one House of Parliament) the six state parliaments mirror the operations and structure of the Federal Parliament. They have two Houses of Parliament (upper and lower), compulsory elections for all citizens over 18 and have ministers appointed from the party or coalition of parties with the majority in the lower house. Some states eg New South Wales, Victoria have scheduled lower house elections each three years and some eg Western Australia have elections scheduled each four years. In the six state Parliaments the leader of the government is termed the Premier.

As with the Federal government, ministers are appointed to be the Parliamentary head of an agency or agencies and are also responsible to the Parliament for the operations of their agencies.

In lieu of the Governor-General, each state appoints a Governor who has similar powers on a state basis to those of the Governor-General, with some minor variations between states. As with the federal system, the Governor must sign Acts of Parliament before they become law. The Governor is appointed by the Parliament on recommendation of the State Executive Council.

Each state has a Supreme Court as well as a series of other courts (eg District Courts, Magistrates Courts) with the Supreme Court of each state being the highest appellant court of each state. Decisions of the state Supreme Courts may be appealed to the High Court of Australia.

Each State Parliament also appoints an Auditor -General to be head of the Auditor-General's Office (AGO) which has responsibility to undertake audits of all state government funded departments and other agencies.

\subsection{Local Government}

The operations and responsibilities of local governments, of which there are over 700 , are not specified in the Australian Constitution and each state has enacted laws 
relating to local government structure, role and responsibilities within their particular state. All local government authorities are subject to the specified laws of each state and have generally have no responsibility for laws in other states and the Federal Government. State governments have extensive powers in regard to local government authorities including the power to dismiss the elected council. Local governments have responsibility for the provision of a wide range of services including the construction and maintenance local roads and footpaths, recreation, aged care, rubbish collection and environmental services.

Local governments are a specified area of a state with detailed boundaries determined in consultation with each State government. Local government authorities are termed by different names e.g. shire, town, city, district council, generally depending on the size of their population. They can range in size in both population and area with some local government authorities exceeding 150,000 square kilometres in area.

Each local government authority is controlled by an elected council with each member of the council being elected by citizens 18 years and over. Voting varies in each state with some states having compulsory voting (e.g. Victoria) and other voluntary voting (e.g. Western Australia). Council members are elected for various periods of time, usually three of four years, depending on the State.

Each elected council appoints the Chief Executive Officer and other required senior members of the local authority and these in turn appoint the other necessary staff required to effectively run the day to day operations. Councils can enact By-Laws for the area of their local authority but are not actually able to enact laws - these are the province of each State Parliament.

The Council of each local authority is required to appoint an independent auditor (not the Auditor-General) who has responsibility to audit the authority and provide an report to the Council. Councils are required to lodge copies of their annual budget and annual reports with the appropriate department of the State Government (e.g. Department of Local Government).

\subsection{Inter-Governmental Relations}

Even though there are distinct structures in place for the various tiers of government in Australia, there are formal and informal mechanisms in place to enable interaction between each tier. Each year the prime minister and the six state premiers hold what is termed a Premiers Conference, a meeting aimed at detailing Federal-State financial relations.

Since 1992 the Council of Australian Governments was established and is the peak inter-governmental forum in Australia (www.aspc.gov.au/about/exppsreform3.htm). It consists of representatives from each tier of government and basically is the main arm for the initiation, development and monitoring of policy reforms which are of national significance.

\section{Reforms in the Chinese and Australian Public Sector}

The public sector in both China and Australia has undergone major reforms in a number of important areas including accountability, governance and financial budgeting 
and reporting. The following section is an overview of the important changes which have occurred and those which various levels of the public sector are still undertaking.

\subsection{Public Sector Reforms in China}

In China, five important reforms have occurred in the government system since 1982 and these are key drives in the development of public accountability within the government system and also governmental accounting and financial reporting. An efficient and effective government system based on law, limited government and open government are regarded as the important purposes of the reforms of the China government system (Mu, 2003). These major reforms have included the following :

- The 1982 Reduction in the Number of Organizations and Staffing in the Central Government

- Initial 1988 Reform: The First Pace of Change in Government Functions

- The 1993 Reforms: Meeting the Needs of the Developing Market Economy

- The 1998 Reforms: Building an Efficient and Effective Government

- The 2003 Reforms: Separation of Decision-Making, Implementation and Supervision

\subsubsection{Reduction in the Number of Organizations and Staffing Within the Central Government}

In 1981, there were 100 entities, e.g. ministries or commissions, of the State Council of China - this was the greatest number of entities within the central government system since the People's Republic of China was established in 1949. It was found that a large and often inefficient government system did not meet the requirements of developing the social and economic needs of an expanding China and the size of government system had to be reduced.

In March 1982, the 22nd session of the fifth National People's Congress approved "The Resolution to Reform the Organizations in State Council" which reduced the number of organizations and staff within the State Council. In this reform, the number of entities within the State Council was reduced from 100 to 61 and the number of staff in all entities was reduced from 51,000 to 30,000 .

\subsubsection{Initial 1988 Reform: The First Pace of Change in Government Functions}

After the first reform of the government system of 1982, the number of branches and staff again increased greatly. As an outcome of this increase the first session of the seventh National People's Congress launched the second reform of the government system in April 1988.

The reforms of 1988 were directed at the administration departments which were closely related to the reform of the economic system in China. The reforms main purpose was to make changes to the functions of government. The government began 
to emphasize the function of macro economic control and indirect management instead of micro-cosmic and direct management.

The reforms were commenced initially in the central government and then moved in a step by step fashion to local government. As a result of the reforms, four ministries or commissions were deleted and staff of the State Council was reduced by over 9,700. These changes to the structure and function of government were regarded as an important purpose of the reform for the first time - this reform, greatly influenced the later reform movement.

\subsubsection{The 1993 Reforms: Meeting the Requirement of a Developing Market Economy}

Reforms to build the market economy system in China were proposed in the $14^{\text {th }}$ session of Chinese Communist Party with the first session of the 8th National People's Congress deciding again to reform the organization system of the State Council. The focus of the reform in 1993 was to separate enterprise-type from administrative organizations and to strengthen macro-economic control and supervision. The previous functions of government of directly examining and approving the operation of enterprises were reduced in these reforms. After the reform, the number of branches of the State Council was reduced from 86 to 59.

\subsubsection{The 1998 Reforms: Building an Efficient and Effective Government}

The first session of the ninth National People's Congress carried out the fourth set of reforms of the organization system of State Council in March 1998. The general goal of these reforms was to build efficient and effective government administration systems and to improve the civil servant system.

The most important purpose of the reform was a move to change the function of government into social administration and to improve the public service. There were three parts to this reform namely (1) changing the structure of the government system and reducing the size of government; (2) adapting the authority of government and avoiding authority overlapping among several governments; (3) strengthening the construction of democracy and law.

After these reforms, the number of all the branches of the State Council was again reduced from 40 to 29. From 1998 to 2002, the reform of the government system was carried out throughout all levels of the government - from central government to local government with the result that to June 2002, there was a reduction of 1.15 million government staff. The 1998 reform was a much larger reform than the previous three.

\subsubsection{The 2003 Reforms: Separation of Decision-Making, Implementation and Supervision}

In March 2003, the first session of the 10th National People's Congress undertook the fifth major reform of the organization system of the State Council. This reform, 
loosely based on the 1998 reforms, was distinctly different from the former one. The social environment in 2003 changed substantially as a result of following aspects: (1) China became one of the members of WTO in 2001; (2) the 16th session of Chinese Communist Party shaped the time table of the development of country in following 20 years. Democratization and legalization in China resulted in more in-depth reforms in the public management system rather than the previous reform which were really only in the organizations structure and staff numbers of the government system. The reform of State Council in 2003 was the first major step of the whole reform process of political system of China.

Within these reforms, the existing model of administrative management systems was improved to meet the requirements of the new political system of China. The most important result of the reform was to establish an administrative system based on the separation of decision-making, implementation and supervision. The supervision aspect included those both within and external to the government system including both the supervision of People's Congresses and of the supervision People's Political Consultative Conference. Another important result of these reforms was the establishment of a new public finance system within China. The new model of government control of the administrative system only included macro economic control, market supervision, social management and the supply of public goods.

\subsection{Reforms in the Australian Government System}

The reforms within the Australian government system have occurred on an irregular basis over the past two decades and have often been dependent on the political persuasion of the governments elected to power by the electors. With Australia being a federation consisting of six states and a federal government, along with the various state-based local government structures, reforms introduced, for example, into one state government do not always flow through to other states. For example, Western Australia requires performance indicators prepared by state government agencies to be subject to audit by the Auditor General of Western Australia. However, this requirement has not been taken up by other state governments. The following quote from the Australian Public Service Commission (2003) summarises the changes and reforms within the Australian government system:

"Successive Australian governments have implemented reforms in the financial, public service and workplace relations fields with the aim of achieving a performance culture within the public sector and of improving the responsiveness of the public sector to the needs of government and the community." (www.aspc.gov.au/about/exppsreform8.htm)

An important reform of the overall Australian public sector occurred through the adoption of a process termed the New Public Management (NPM) program which was a process of change originating from the United Kingdom. NPM is basically a process of 'managerialism' (Guthrie and English, 1997) whereby the public sector adopts private sector management techniques (Parker and Gould, 1999). Within NPM 
concepts of performance, economy, efficiency and effectiveness have replaced the less measurable and very detailed aspects previously adopted by the public sector (Brignall and Modell, 2000).

A study by David et al. (1986) claimed the concept of managerialism includes five important characteristics, these being:

- Greater managerial autonomy through delegation and devolution of ministerial authority

- Clear, consistent objectives

- Performance evaluation

- Rewards and sanctions

- Competitive neutrality for commercial authorities

These important changes in the Australian public sector with the adoption of accountability, transparency, NPM and reporting reforms means that "public sector management has transformed from being administrators and custodians of resources to being accountable managers empowered with greater delegated authority" (Parker and Gould, 1999: 110). With the adoption of NPM and other major public sector reforms, Australia has become one of the world leaders in public sector reform and accountability.

An important change progressively implemented into the public sector was the requirements for government agencies to establish and achieve specified performance criteria or performance indicators. This concept has been termed by a number of names including Performance Based Budgeting in Western Australia. Performance indicators. Performance indicators are normally seen as a numerical measure of achievement that is easy to collect and use. In theory, they can only be derived for items over which an organisation has control. However in reality entities do not have absolute control over everything and therefore control is actually a matter of whether there is enough control for your purpose (Bullen, 2003).

A definition of performance indicators from the United Kingdom Office of Public Management is:

"A performance indicator defines the measurement of a piece of important and useful information about the performance of an program expressed as a percentage, index, rate or other comparison which is monitored at regular intervals and is compared to one or more criterion" (Bullen, 2003: 7).

By definition performance indicators must be about performance rather than the activities undertaken or the level of workload. Occasionally activities and performance are directly related, as for example, the number of people vaccinated is a good indicator of both the performance achieved (people vaccinated) and the activities undertaken by medical staff (the number of injections given). However, outcomes and activities are often not so directly related (Bullen, 2003).

A number of researchers have suggested that government performance needs to measure economy, efficiency and effectiveness (for example, Kloot, 1999) Economy is defined as acquiring resources in appropriate quantity and at least cost whilst efficiency is defined as maximizing output for a given set of inputs, or minimizing inputs for 
a required output. Together, economy and efficiency are consistent with notions of financial accountability of both federal and state government.

A further reform introduced by all state governments and the federal government has been in the area of budgets where funds are allocated on a program or similar basis with specified outcomes from the program. This was a major change from the previous budget system where funds were allocated to a particular agency on a 'minute' budget allocation process. In this process funds were specifically allocated by type of expenditure e.g. salaries, stationery, repairs and maintenance etc, and agencies were not permitted to exceed their budgets on a particular item.

Under the program (or functional area) budgeting methods funds are allocated by Parliament to a particular program and the government agency is expected to operate within the budget and achieve its specified outcomes.

\section{Financial Reporting Systems of the Public Sector}

Since the 1980s major reforms of the reporting practices of the public sector have occurred in both China and Australia. As detailed above China was also undertaking a fundamental reform of its public sector structure and accountability and required reporting practices to reflect these changes. In addition since China was admitted to the World Trade Organisation (WTO) further major reforms have occurred within the Chinese public sector to reflect the change to a more market driven economy. Australia has also undergone reforms to the reporting practices with these being undertaken as a result of calls for greater and more transparent accountability and also better and more efficient and effective use of public funds.

The following section details the major financial reporting changes which have occurred in China and Australia over the past two decades.

\subsection{Financial Reporting Reforms in China}

Within China, there are close relationships between the evolvement of governmental accounting and reporting requirements and the reforms of the government system. The two major changes in governmental accounting and reporting requirements happened in 1998 and 2006.

\subsubsection{The 1998 Changes of Governmental Accounting and Reporting Requirement}

Previously in China, the governmental accounting system was composed of general budget accounting for public finance, executive entity accounting, institution accounting, treasury accounting, tax collection accounting and infrastructure accounting. In 1998 the Ministry of Finance enacted four new public sector accounting regulations which reformed the government system and assisted the development of the market economy system. These new regulations were: 
- Regulation of General Budget Accounting for Public Finance

- Regulation of Executive Entity Accounting

- Accounting Standards for Institutions (draft)

- Regulation of Institution Accounting

Although the regulations for the reform of the public sector accounting system played an important role in the reform of government system, there were some limitations in the accounting requirement system of 1998.

Firstly, after 1998, there was a major change in the budget accounting environment in China. This change was due to a series of budget management reforms being adopted, including departmental budgets, separation between government revenue and expenditure, government procurement, and establishment of only one account for the Treasury. All these reforms of the budget management system had major influences on the budget accounting system of 1998. Secondly, the budget accounting system did not meet the new public finance requirements. Thirdly, the regulations for general budget accounting of public finance, executive entity accounting and institutional accounting required three different types of accounts and financial statements. This posed a problem for users of public sectors' accounting information as they were unable to obtain comparable information from the different financial statements.

Fourthly, the budget accounting system only supplied information about the budget implementation, which cannot meet the needs of users. Fifthly, the budget accounting system was useful only to internal governmental users, not to external users out of the government financial reports.

\subsubsection{The 2006 Changes to Governmental Accounting and Reporting Requirement}

In February 2006, the Ministry of Finance of China enacted a scheme for the reform of classifications of revenue and expenditure of government. This reform was aimed at meeting the requirement of transformation of the government sector and the establishment of a new public finance system.

The improved classification system of revenue and expenditure of government was composed of three major parts including revenue classification, expenditure classification based on function and nature and expenditure classification based on economic nature.

\subsection{Financial Reporting Reforms in the Australia Public Sector}

During the 1990s, all tiers of the public sector in Australia (Federal, State and Local) commenced the process of reforming their accounting and reporting practices to conform with changing trends around the world. The aim of the financial management reforms were to (www.apsc.gov.au/about/exppsreform8.htm):

- Put the public sector on a more business-like footing

- Foster a more competitive environment

- Shift the focus from complying with rules to managing for results

- Plan, budget and report on an accruals, outcomes and outputs basis 
The reforms were introduced at varying times in different tiers of the public sector and the introduction was dependent on the legislative process of the individual governments. These changes included the introduction of accrual accounting, which required the recording and reporting of all assets and liabilities along with revenue and expenses, accrual-based budgeting and the preparation of full forward estimates. A later reform has been the greater recognition and overview of risk management by government entities.

As a result of these reforms, for example, all public sector agencies at federal, state and local government levels are required to prepare financial reports on the accrual accounting basis, as per the private sector. These changes involved major implications for the public sector including the identification of all assets, including those of a heritage or infrastructure nature, recording and valuation of assets, the identification of all liabilities including those relating to employees entitlements e.g. leave and superannuation entitlements and developing higher levels of financial capabilities amongst staff. The identification and valuing of public sector assets, including examples such as land under roads and cultural collections, has proven to the source of great debate amongst both supporters and opponents of assets valuation. However, the process of identification and valuation is continuing so that all assets are recorded on the state and national asset registers.

Within Australian all agencies within the public sector are required to report not only on the basis of the appropriate accounting standards but they must also conform with various public sector reporting regulations. For example the Western Australian state legislation is termed the Financial Accounting and Audit Act (FAAA) and the local government regulations are termed the Local Government Financial Management Regulations. The various legislations require the inclusion of additional information within the public sector financial reports to provide further information of the government agency to users of the reports.

One of the major differences between the public sector and the private sector is that the majority of public sector entities do not operate on the basis of profit but provide services to the community on the basis of allocations of budget funding. In order to provide further meaningful information to users, many government agencies in Australia have now introduced a more integrated form of financial reporting for their budgets and annual financial reports. This integrated reporting now often includes some form of performance reporting using various types of performance indicators including those detailing workload, cost, outputs and the newer indicators of effectiveness and efficiency (Mucciarone and Neilson, 2006).

\section{Summary}

Government accounting and financial reporting aims to protect and manage public money and discharge accountability (Chan, 2003). This paper reviews the accountability and structure of government and the public sector in both China and Australia and found considerable differences in the foundations of the current governmental structure and also in the manner in which these structures have evolved. China is a country with a population in excess of 1.3 billion with a history which can be traced back 
several thousand years through the long period of emperors to a federal government to the current central government system. China has evolved, via a major revolution, to a system whereby the Central government has strong power and influence over the decision making and accountability of all lower level governments whether they are at province, city or rural level. In addition the Chinese Communist Party also has major control and influence over all levels of government including the Central government in Beijing. The central decision making body of China is the National Peoples Congress with deputies elected from throughout the country.

In contrast Australia is a relatively new county having being settled by British settlers in 1788 thus with a history of just over 200 years. Australia was then explored and settled on a piecemeal system so that by federation in 1901 there were six colonies who came together to form the Commonwealth of Australia. The Australian federal government system is based on a structure of one federal government, six state governments and a large number of state-based local governments. Each of the three tiers of government (Federal, State and Local) are basically independent structures with elections held independently for each tier on a regular time period. Responsibilities for the provision of services are specified by the Australian Constitution for the federal and state governments and by state legislation for local governments.

Within both countries, major reform processes have taken place in order to make the public sector more accountable, transparent and able to provide improved reporting systems and processes. The Central government in China has undertaken five important reforms since 1982 in a drive to improve accountability, governmental processes, budgeting and financial reporting. These have occurred in 1982, 1988, 1993, 1998 and 2003 with the last reform in 2003 being of major importance to the decision-making and structure of the public sector. This was partly driven by China's membership of the WTO in 2001 and a desire to bring China's public management system to a more modern and useful system (Qi, 2007b). The reforms have been an important catalyst in driving public sector change in China and have resulted in the separation of decision-making, implementation and supervision within the Central-based government (Qi, 2007b).

Public sector reforms in Australia, based on a federalist model, have been more piecemeal and have often relied on the political will of the government in power at the time reforms are introduced. These reforms have been introduced at varying times in all tiers of the public sector (Federal, State and Local) and have generally resulted in a more transparent and accountable form of government. At the present time different tiers of the public sector are at differing stages of the reform process with the local government sector tending to be the last tier to commence the reforms many of which are imposed by the federal and state government levels.

In the area of financial reporting reforms, both China and Australia, over the past 20 years, have undertaken reforms in the area of financial accounting and reporting to conform with changing world trends. China has undertaken two major changes (in 1998 and 2006) which have included revisions to the methods of budgeting and the clarification of revenue and expenditure by all levels of government. These changes have been made in order to provide more useful information to both internal and, importantly, external users. China however has continued to base its current reports 
on the cash system and the public sector has not fully embraced the accrual system of accounting (Qi, 2007a).

Australia has undertaken major reforms to the contents and formats of public sector financial reports commencing with a move to accrual accounting and reporting and the implementation of specific accounting standards for the public sector. These changes have moved on and now Australia has adopted the Australian equivalents of the International Financial Reporting Standards. In addition both federal and most state governments have implemented or are moving towards implementing further reforms including accrual-based budgeting, performance reporting and three year budget projections.

In summary even though the systems of government and structure of the public sector in both China and Australia are distinctly different (Central system versus Federal system), they have both moved to make the government structures and public sector more transparent and accountable and are continuing to implement reforms to increase efficiency and effectiveness of government services.

\section{References}

Australian Parliament, Parliament of Australia - An Overview at www.aph.gov.au/parl.htm (11 Jan 2007).

Australian Public Service Commission, Available at www.apsc.gov.au/about/exppsreform8.htm (23 January 2007).

Brignall, S. and Modell, S. (2000), An Institutional Perspective on Performance Measurement and Management in the New Public Sector, Management Accounting Research, Vol. 11, No. 3, 281-306.

Bullen, P. (2003), Performance Indicators, Available: [http://www.map1.com.au/A1A.htm] (3 September 2003).

Central Government of China at http://www.gov.cn/test/2005-06/15/content_18253.htm) (12 January 2007).

Constitution of the People's Republic of China, 2004.

Davis, G., Weller, P. and Lewis, C. (1989), Corporate Management in Australian Government, Macmillan, Sydney.

Department of Foreign Affairs and Trade at www.dfat.gov.au/facts/sys gov.html (11 January 2007).

Department of the Prime Minister and Cabinet, www.dpmc.gov.au/guidelines/executive handbook/2functions. cfm (11 January 2007).

Economic Zones of China at http://zhidao.baidu.com/question/5368429.html?si=1.

Guthrie, J. and English, L. (1997), Performance Information and Program Evaluation in the Australian Public Sector, Journal of Public Sector Management, vol. 10, no. 3.

Chan, James (2003), Government Accounting: an Assessment of Theory, Purposes and Standards. Public Money \& Management, 1.

Kloot, L. (1999), Performance Measurement and Accountability in Victorian Local Government, International Journal of Public Sector Management, Vol. 12, No. 7, 565-584 .

Mu Qiao (2003), Unscramble New Government, History of Chinese Communist Party Press.

Mucciarone, M. and Neilson, J. (2006), Performance Disclosures by Australian Government Entities, Working Paper, School of Accounting, Curtin University of Technology.

Parker, L. and Gould, G. (1999), Changing Public Sector Accountability: Critiquing New Directions, Accounting Forum, Vol .23, No 2, 109-136.

Qi, Zhang (2007a), Accounting Sector and Users of Accounting Information in China Government, Journal of Finance and Accounting (China), December.

Qi, Zhang (2007b), Several Qualification China Governmental Accounting System Have to Satisfy before Reform Happen, Journal of Finance and Accounting (China), October. 
Qi, Zhang (2006a), Apply Accrual Basis to Government Accounting Moderately: Factors and Enlightenments, Journal of Finance and Accounting (China), September.

Qi, Zhang (2006b), To Establish a Performance Measurement Oriented Government Accounting System, Accounting Research (China), April. 
(Página deixada propositadamente em branco) 


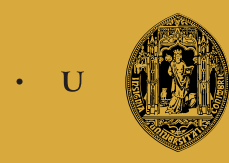

C - 